\title{
Immigration and the Informal Labor Market*
}

\author{
Lídia Farré \\ Universitat de Barcelona and IAE-CSIC \\ Mariano Bosch \\ Interamerican Development Bank
}

\begin{abstract}
This paper investigates the relationship between immigration and the size of the informal or underground economy. Exploiting the variation across Spanish provinces we find that the massive immigration wave between 2000 and 2009 is highly correlated to the share of unregistere demployment, a proxy for the size of the underground or informal labor market. We estimate that a 10 percentage points increase in the share of immigrants in a province generates between a 3 and 8 percentage points increase in unregistered employment. We also find that the controversial regularization of illegal aliens conducted in 2005 substantially reduced the number of illegal workers butdidnot affect the relationship between immigration and informality. In contrast, we do find that this relationship becomes stronger during the economic recession inaugurated in 2008.
\end{abstract}

Keywords: immigration, informal economy, amnesty, economic recession.

JEL classification: J61, O17.

\section{Resumen}

Este artículo analiza la relación entre inmigración y el tamaño de la economía sumergida. La explotación de los datos sobre la variación en las distintas provincias españolas, refleja que la ola de inmigración máxima habida en los años 2000-2009 está estrechamente relacionada con el tamaño del empleo no registrado, un buen indicador de la magnitud del mercado de trabajo sumergido. Se estima que un incremento de 10 puntos porcentuales en la tasa de inmigración en una provincia, genera un aumento entre 3 y 8 puntos porcentuales del empleo no registrado. Por otra parte, se observa que la controvertida regularización de trabajadores ilegales llevada a cabo en 2005, redujo sustancialmente el número de estos trabajadores pero no afectó a la relación entre inmigración y mercado de trabajo sumergido. En cambio, se encuentra que esta relación se intensifica durante la recesión económica que comenzó en 2008.

Palabras clave: inmigración, economía sumergida, amnistía, recesión económica.

Clasificación JEL: J61, O17.

\section{Introduction}

The informal or underground economy is a widespread phenomenon, not only in developing countries but also in developed ones. In 2003 the size of the informal sec-

* Farré acknowledges the Government of Catalonia (grant 2009 SGR 896) and the Spanish Ministry of Science (grant ECO2011-29663) for financial support. 
tor represented, on average, a 17\% of the GPD in the OECD economies. In southern European countries like Greece, Portugal and Spain the informal sector accounted for up to a $30 \%$ of the GDP. The reasons for participating in the informal economy are highly debated in the literature (see Schneider and Enste, 2002), and range from pure tax evasion to a last resort activity in the face of high unemployment.

One of the main sources of the recent increase in informality in developed countries is the massive inflows of undocumented immigrants from developing economies attracted by job opportunities and the dream of a better life. Indeed, a large proportion of the foreign born labor force in most OECD countries are illegal or undocumented aliens $(63.5 \%$ of all foreign residents in the US in 2007, 25.6\% in Italy in $2005,21.2 \%$ in the UK in 2005 or $13.4 \%$ in Spain in 2007) ${ }^{1}$. They are primary, individuals who entered the country surreptitiously over green or coastal borders; fraudulently by means of false documents; or legally through a temporary visa or permit (i.e. tourist or family-visit visas) followed by an overstay. They may also include asylum seekers who do not leave the hosting country if the application is denied $^{2}$. Even if immigrants hold legal status they may be irregularly hired in the informal labor market, especially when underground activities are already common in the economy, as they are in southern Europe ${ }^{3}$.

This paper documents the relationship between immigration and the size of the informal labor market in Spain over the last decade. During this period the percentage of the foreign born population shifted from 3\% in 1998 to $14 \%$ in 2009. Since the late 2000's, the stock of immigrants has stabilized as a result of the severe economic and financial crisis that hit the country's economy (see Figure 1).

The inflow of immigrants that arrived to Spain during the last decade represents one of the major migration waves in recent history and clearly reshaped the structure of the Spanish labor market (see for example González and Ortega, 2010). At the same time, the restrictive immigration policy and the weak border and work place enforcement stimulated the growth of illegal alien employment. In the attempt to draw immigrants out of the back economy the government conducted a series of amnesties. The most recent one in 2005 received 691,655 applications for regularization out of which 572,961 were approved ${ }^{4}$. In this paper we also investigate the effectiveness of this large and contested regularization process in decreasing the size of the informal labor market ${ }^{5}$.

\footnotetext{
${ }^{1}$ Estimates based on a number of different methodologies (OECD, 2009).

${ }^{2}$ Estimates of the distribution of unauthorized immigrants by modalities for a number of countries suggest that overstay is the most common form of illegal immigration.

3 Among the OECD countries for the period 1999-2001, Greece, Italy and Spain had the largest shadow economies, at approximately $30 \%$ of GDP. In the middle group were the Scandinavian countries and at the lower end were the United States, Austria and Switzerland at 10\% of GDP (SCHNEIDER and ENSTE, 2002).

4 Source: Ministry of Labor and Foreign Affairs.

5 In 2005 the size of the foreign born population according to the Registry data collected by the Spanish Satistics Office was 4,391,484..
} 
Research on this topic is scarce mainly due to the difficulty in measuring illegal immigrants and the size of the informal economy (Chiswick, 1988). Only a few developed countries such as the United States, Australia, Japan and Korea release regular statistics on this issue. Our estimates of the contribution of immigration to the size of the informal labor market in Spain are based on comparisons between the official employment records of the Social Security and that in the Labor Force Survey. The first includes workers with a legal working contract while the second reflects the number of people legally or illegally engage in an economic activity. Our identification strategy exploits the cross-regional correlation in the difference between these two employment measures and the immigration inflow into each province over the last decade. We instrument the current distribution of immigrants across Spanish provinces using historical immigration settlements in the country (i.e. an instrument based on ethnic networks).

Our findings point to a strong relationship between immigration inflows in a province and the discrepancies between registered and total employment. In particular, a 10 percentage points increase in the share of immigrants in a province increases informal employment by 3 to 8 percentage points, depending on the specification. We also find that the 2005 amnesty which regularized hundreds of thousands immigrants, while reduced the stock of illegal aliens, did not affect the relationship between immigration inflows and the size of the informal labor market.

The vibrant activity of the Spanish economy during the past decade was the main pull factor to drive up immigration. Between 2002 and 2007 the country received an impressive inflow of immigrants -approximately 500,000 per year- who were quick to find jobs, mainly in the booming construction and service sector. However, the international financial crisis of 2007 severely hit the country's economy. One of the most negative consequences of the economic downturn was the dramatic increase in the unemployment rate, to levels above 25 per cent in 2012. At the close of the paper we also investigate the implications of the economic recession for the estimated relationship between immigration and the size of the shadow economy.

The paper is organized as follows. The next section presents a brief description of the Spanish immigration history and its related policy. Section 3 contains a description of the data. Section 4 presents the empirical strategy, our results and robustness checks. Some concluding remarks follow.

\section{Immigration to Spain}

International migration to Spain has been on a rising trend since the mid-1990s, with labor migration taking on a greater role since the early 2000s. The foreign born population jumped from 1,173,767 in 1998 to 6,466,278 in 2009. After this period, the stock of immigrants has remained almost constant as a result of the economic recession that hit the country (see Figure 1). The yearly stock of immigrants is measured from the Registry data annually collected by each municipality. Immigrants have 
FIGURE 1

\section{EVOLUTION OF IMMIGRATION IN SPAIN}

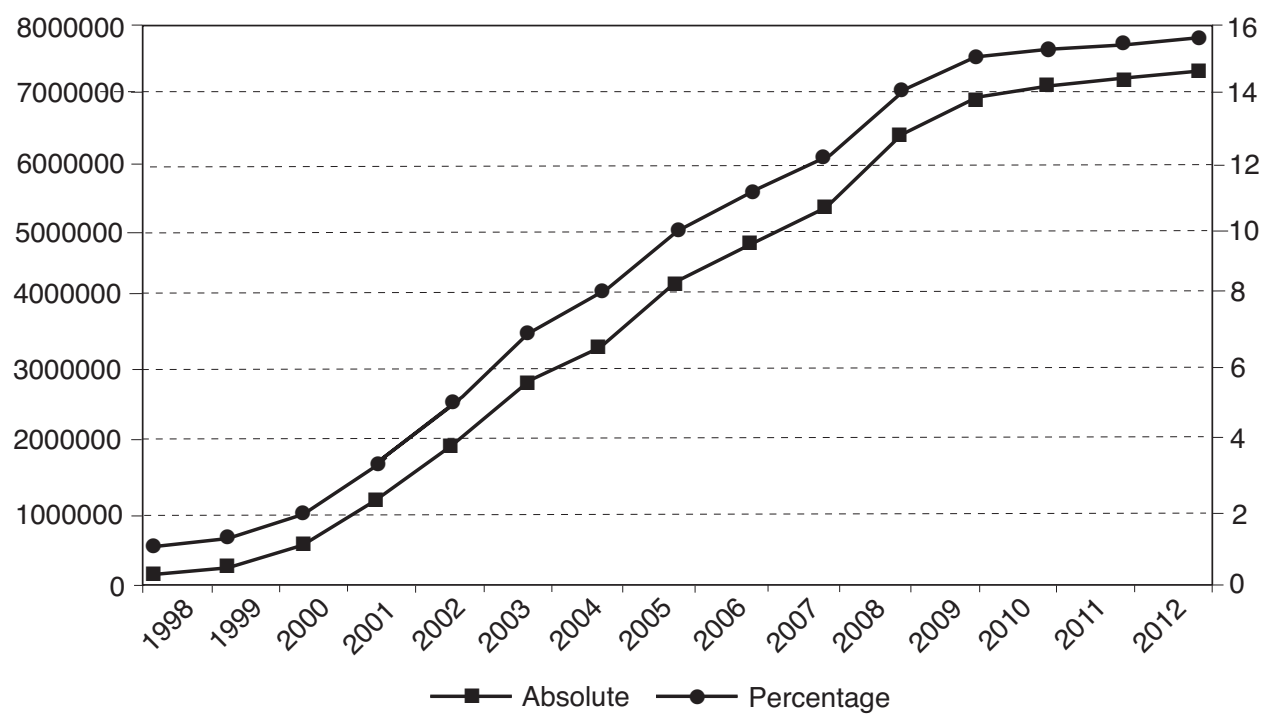

NOTE: Registry data (Padrón Municipal), Spanish Statistical Office. Absolute refers to the foreign born population in millions and Percentage refers to the percentage over the total population.

strong incentives to register as this grants free access to the health and educational system. Registration also represents a valuable piece of evidence to prove residence in the country in the event of future amnesties. Thus the numbers obtained from the Registry provide an accurate estimate of the size of the foreign born population, including undocumented aliens.

The economic expansion of the last decade made of Spain a very attractive destination. Moroccans, for their geographical proximity, Latin Americans, given the small cultural gap and common language, and other Eastern European groups, mainly Rumanians, represented the bulk of immigrants over this period ${ }^{6}$. The construction boom attracted male low-skilled workers, whose spouses or relatives found jobs in the care giving and service sector ${ }^{7}$.

The scarcity of legal entry channels to fill low skilled jobs suggests that a substantial proportion of the foreign born population entered the country illegally or overstayed once their visa or temporary permission expired ${ }^{8}$. This conjecture is

${ }^{6}$ In 2009 Rumanians represented a $11.79 \%$ of the foreign born population, Moroccans $11.49 \%$, Ecuadorians $7.41 \%$, and Colombians a $5.55 \%$.

7 See GONZÁLEZ and ORTEGA (2010) and FARRÉ, GONZÁLEZ and ORTEGA (2009).

${ }^{8}$ Prior to the 1970 s, Spain was an emigrant country (Spaniards first emigrated to South and Central American and Africa and later to Northern Europe). The first Spanish law to restrict immigration was passed in 1985. The law required a job offer to apply for a work visa or residence permit. There have been 
supported by Figure 2 that compares the total number of foreign born recorded in the municipal Registry and those with a valid residence permit according to the data released by the Spanish Ministry of Labor and Foreign Affairs. The Figure indicates that the number of illegal aliens has shrunk over the second half of the last decade, particularly after the last regularization in 2005, however unregistered aliens still represent a $15 \%$ of the foreign born population in 2009.

FIGURE 2

\section{EVOLUTION OF DOCUMENTED AND UNDOCUMENTED IMMIGRATION IN SPAIN}

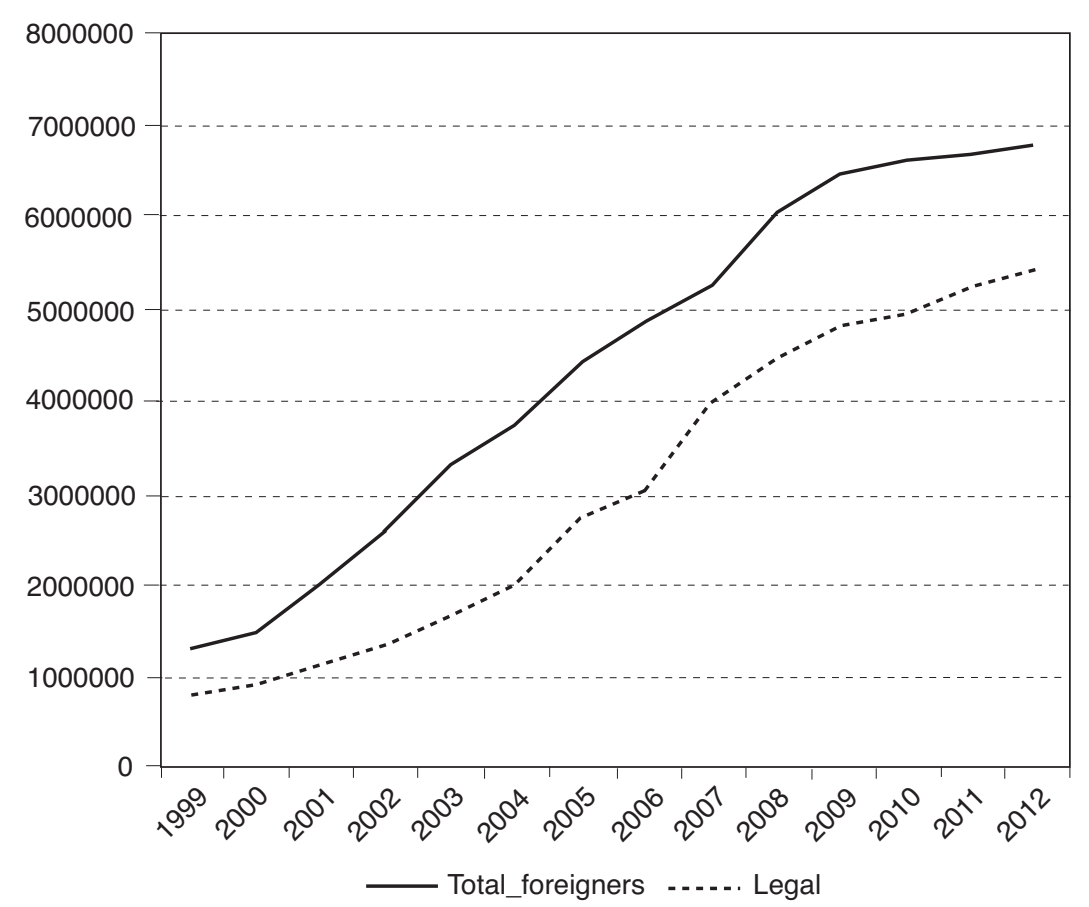

NOTE: Registry data (Padrón Municipal), Spanish Statistics Office (Spain) and Spain Ministry of Labor and Foreign Affairs, legal refers to foreigners with a valid residence permit Total foreigner velers to the total foreign population recorded in the Population Registry.

several amendments aimed at expanding the rights and opportunities of foreigners, but a job offer is still mandatory to obtain a work or residence permit. In 2002 the government established a system of annual quotas to hire foreign workers from their country of origin. In 2003 the quota was fixed at 24.337 workers and expanded to 27.034 in 2007. As a result of the economic recession the quota for permanent workers decreased by about $90 \%$ in 2009 . 
Another estimate of the size of the unauthorized foreign born population at a particular point in time can be obtained from the results of the 3 consecutive amnesties conducted in Spain between 2000 and 2005. The first one in 2000 resulted in 153,463 out of 247,598 applications being approved, mostly to citizens of Morocco, Ecuador, Colombia and China. After the first regularization the government implemented a number of legal reforms aimed at restricting labor inflows. The reforms not only were not effective in dissuading immigrants from arriving in record numbers, but also boosted undocumented labor since an employment contract was required to enter the country legally to work. In an attempt to control the inflow of immigrants who had entered the country without a contract and were hence working illegally, the government announced a second amnesty in 2001. Approximately 350,000 applications were received, and 221,083 permits were issued to citizens mainly from Ecuador, Colombia, Morocco and Romania. The immigration inflow did not stop and in 2005 Spain executed the largest regularization program to date. About seven hundred thousand workers from Ecuador, Romania, Morocco and elsewhere applied to regularize their immigration status. To qualify, they needed proof of residency in Spain since at least August 7, 2004, a work contract of at least six months' duration, and no criminal records. About $83 \%$ of the applications received were approved. Note that applications for regularization should be considered a lower bound for the presence of undocumented immigrants as the requirements already excluded from the process recent immigrants (less than a year), those with an illegal contract or involved in criminal activities.

Even when holding a legal status immigrants are frequently hired irregularly as it is a cheap and flexible alternative for employers to cover their labor needs. Among the main concerns raised by informal employment are: i) the weak social protection for the workers themselves; ii) the fact that informal employment is often a trap which offers few prospects to improve careers; iii) its consequences for workers in the formal economy, who suffer unfair competition and have to pay higher taxes than in the absence of informal employment; iv) potential rewarding of tax evasion and corruption associated with government inability to enforce the rule of law.

In what follows we investigate the contribution of immigration to the size of the informal labor market. We conduct a spatial correlation approach and exploit the variability in immigrant density and unregistered employment across Spanish provinces over the period 2000 to 2009. At the close of the paper we also extend the analysis to the period 2010-2012 to investigate the implication of the economic downturn for our finding. Crucial to our identification strategy are the important differences in the regional concentration of immigrants over the period. For example, the immigrant share, defined as the working age foreign born population over the total working age population, shifted from about $5 \%$ to more than $25 \%$ in regions along the Mediterranean coast, such as Murcia, Girona, and the Balearic Islands, while it remained below 5\% over the all period in some Southern regions (Córdoba, Jaén y Badajoz). 


\section{Data}

Gathering information about underground economic activity is difficult, because no one engaged in such activity wants to be identified. Disagreement persists about definitions and estimation procedures (see Schneider and Enste, 2002). Regarding its definition, the OECD (1986) proposed to define "concealed employment" as "employment (in the sense of the current international guidelines on employment statistics) which, while not illegal in itself, has not been declared to one or more administrative authorities...". The EU (1998) similarly defines "undeclared work" as "any paid activities that are lawful as regards their nature but not declared to the public authorities, taking into account differences in the regulatory system of member States. Applying this definition, criminal activities would be excluded, as would work not covered by the usual regulatory framework and which does not have to be declared...". We relay on the previous definitions of informal employment and use the data available in Spain to quantify the contribution of immigration inflows to the discrepancies between the employment recorded in the Spanish Labor Force Survey, $L F S$, (Encuesta de Población Activa, EPA) and the number of legal contracts in the Social Security records, SS.

The Labor Force Survey collects quarterly information on the employment status of the household members in Spain. In the survey a person is considered to be employed if he or she did some work for pay during the week previous to the interview. The survey does not distinguish between formal and informal employment. As those in an irregular employment situation have less incentives to declare their economic activities, the size of the informal labor market obtained from the Labor Force Survey should be considered a lower bound. There are other issues that are likely to affect the size of the informal economy calculated from the LFS. First, it does not collect information on individuals not living in households (i.e. living in pensions or hotels) which represent less than $1 \%$ of the population ${ }^{9}$. Second, it does not contain an accurate representation of temporary foreign workers as those do not have a residence in Spain. In 2005, however, the design of the LFS was modified to better capture the presence of the foreign born population. These corrections can be retrospectively applied to the LFS series from 1996 to 2004, thus guaranteeing its continuity since 1996.

The Social Security records contain information on all workers (employees and self-employed) with a legal employment contract. The information is published on a monthly basis and reflects the number of persons legally working as the last day of each month. There are some aspects of the Social Security records that should be considered when analyzing the discrepancies with the employment numbers in the Labor Force Survey. First, civil servants may choose to be affiliated to the Social Security system or to a private system. Those choosing the latter alternative do not appear in the Social Security records. Second, agriculture workers holding

\footnotetext{
${ }^{9}$ This estimation is provided by the Spanish Statistical Office.
} 
a temporary contract appear as employed in the Social Security records during the total length of the contract even if they do not work during the month of reference. Third, the members of the clergy are considered by the Social Security records as employed, and this is not the case in the Labor Force Survey. Fourth, the Social Security records double count self-employed individuals holding a second legal labor contract with an employer. Finally, individuals employed in the household service sector and working less than 20 hours per week are not oblige to be registered in the Social Security records.

Below we assess the contribution of immigration to the discrepancies between the employment recorded in the Labor Force Survey, that should include legal and illegal workers, and that in the Social Security records, that include only legal workers. As becomes clear from the previous discussion, we can not interpret the difference in employment between the two data sources as solely due to informal employment. However, we next argue that our analysis allows us to draw some conclusions on the impact of immigration on the size of the informal labor market.

Our empirical approach correlates annual changes in the differences between employment in the LFS and the $S S$ records and changes in immigration densities across provinces between 2000 and 2009. Our conjecture is that immigration has increased the size of the informal labor market as many immigrants enter the country illegally and even if they hold a legal status they are illegally hired by employers. Our strategy will identify the contribution of immigration to the illegal economy under the assumption that the methodological discrepancies between the LFS and the $S S$ records are constant over time or unrelated to immigration flows.

As already mention the LFS will only capture a lower bound on the size of the informal labor market as temporary foreign workers and individuals not living in households are not included in the survey. These two type of individuals, particularly those in the former group are likely to have increased with the immigration boom of the 2000s. Regarding other type of workers that contribute to the differences between the LFS and the SS records, we think that it is reasonable to assume that civil servants affiliated to a private security system, members of the clergy and self-employed with a second contract have remained a constant fraction of the population or that their variation are not related to immigration flows. The two type of workers that contribute to the differences in employment between our two data sources and which percentage in the population may be related to immigration are agriculture workers employed on a temporary basis and workers in the household service sector. We investigate the robustness of our results by excluding these workers from the analysis.

\section{Empirical Analysis}

The core of our analysis employs the differences between the Labor Force Survey and Social Security records. We do not claim that those differences are an unbiased estimate of the size the informal sector in Spain. What we do claim is that those 
differences are informative about the evolution of the size of the informal economy over time. With this in mind Figures 3 plots those differences at the aggregate country level for the period 2000-2009 in absolute and in percentage terms. A few comments merit attention. First, at the beginning of the decade the LFS showed 400.000 workers more than the SS records. This corresponds to a $2 \%$ out of the approximately 20 million workers in the Labor Force Survey. Second, these differences tripled (to 1.2 million workers and 6\%) during the period 2000 to 2005. After 2005, coinciding with the amnesty, the differences stabilized and remained about $6 \%$ of total employment recorded in the LFS. Note that by the end of the period and coinciding with the economic downturn this percentage fell to 5\%. Figure 4 shows these differences (as a percentage of employment in the Labor Force Survey) by nationality. The picture is astonishing. Whereas for nationals only around $2 \%$ of employment is unregistered, for foreigners this ratio is less than $10 \%$ at the beginning of the period and reaches $40 \%$ in 2005 . Interestingly, the 2005 regularization process halved the share of unregistered workers to $20 \%$ but in the subsequent years unregistered work increased back to $30 \%$.

Figure 4 suggests that the large increase in unregistered work during the first part of the decade is tightly linked to the increase in the number of immigrant workers. Further evidence of this relationship can be obtained by exploring the regional patterns of those discrepancies. Figure 5 displays the relationship between the growth in the share of foreign born population and the growth in unregistered employment by province for the period 2000-2009. There is a clear positive correlation between immigration growth and the share of unregistered work. If we fit a linear regression to the data in Figure 5 the estimate on the slope coefficient indicates that a 1 percentage point increase in the share of foreigners in the province is associated to a 0.36 percentage points increase in the provincial share of unregistered work, and this effect is significant a the $1 \%$ level of significance. Below we analyze the robustness of this correlation and investigate whether it can receive a causal interpretation. 
FIGURE 3

DIFFERENCES BETWEEN THE LFS AND THE SS RECORDS

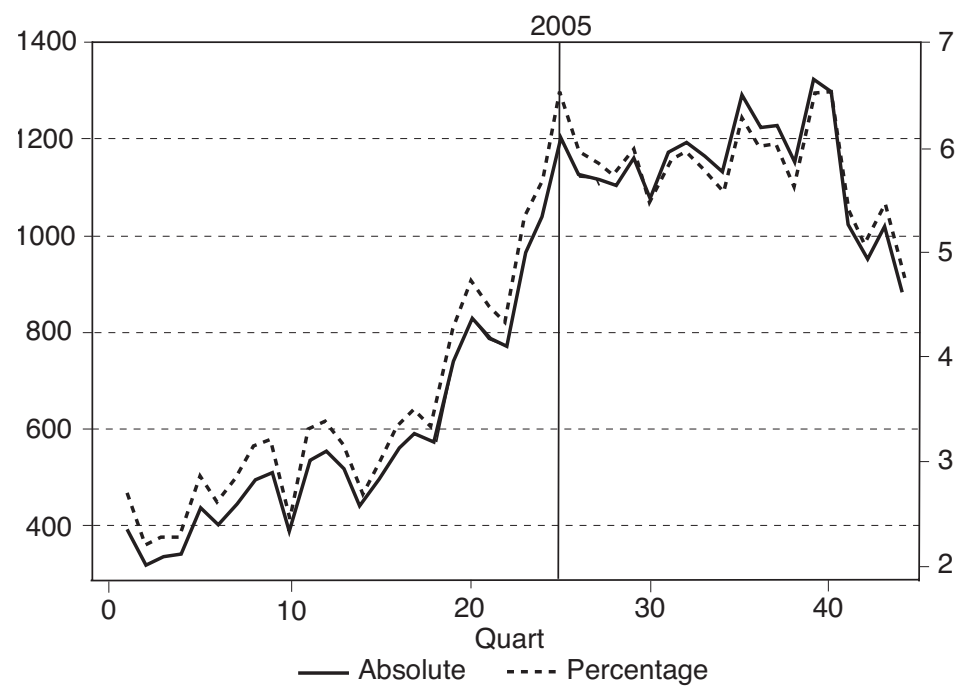

NOTE: Period 2000-2009. Quarterly differences between the number of the employed workers according to the Labor Force Survey and the Social Security records. Absolute refers to the absolute number of workers in thousands Percentage refers to the percentage that the absolute difference represents over total employed workers in the Labor Force Survey.

\section{FIGURE 4}

DIFFERENCES BETWEEN THE LFS AND THE SS RECORDS BY NATIONALITY

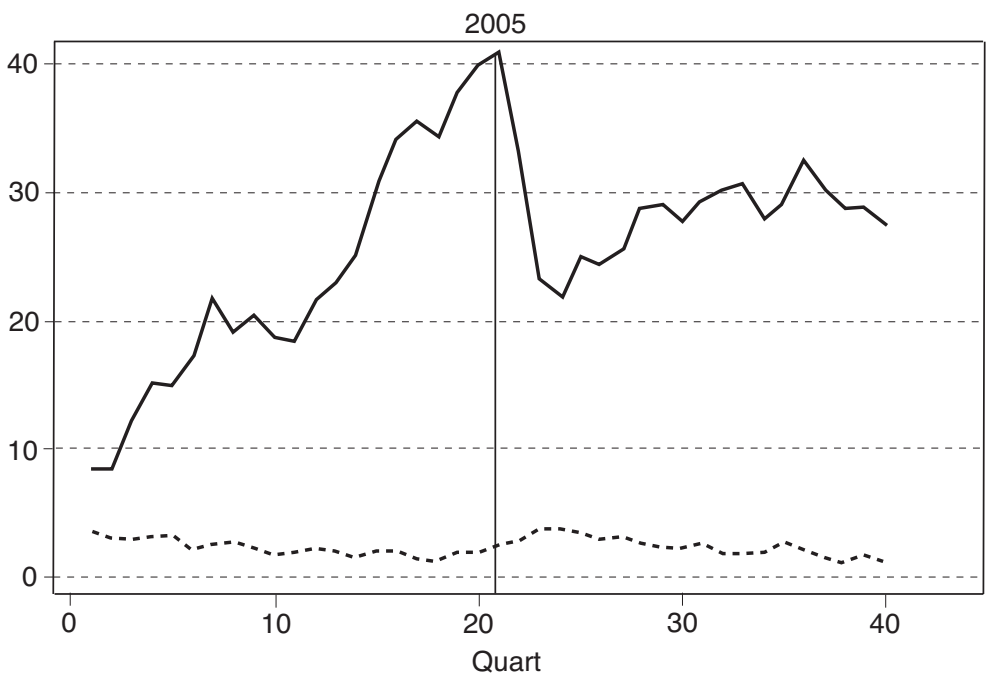

Per_foreigners

Per_domestic

NOTE: Period 2000-2009 (quarters). The graph plots the difference between employment in the LFS and the SS records as a percentage of total employment in the LFS, separately for foreigners and domestic workers (i.e. natives and foreign born workers with Spanish nationality). 
FIGURE 5

\section{IMMIGRANT CONCENTRATION AND SIZE OF THE INFORMAL SECTOR AT PROVINCIAL LEVEL}

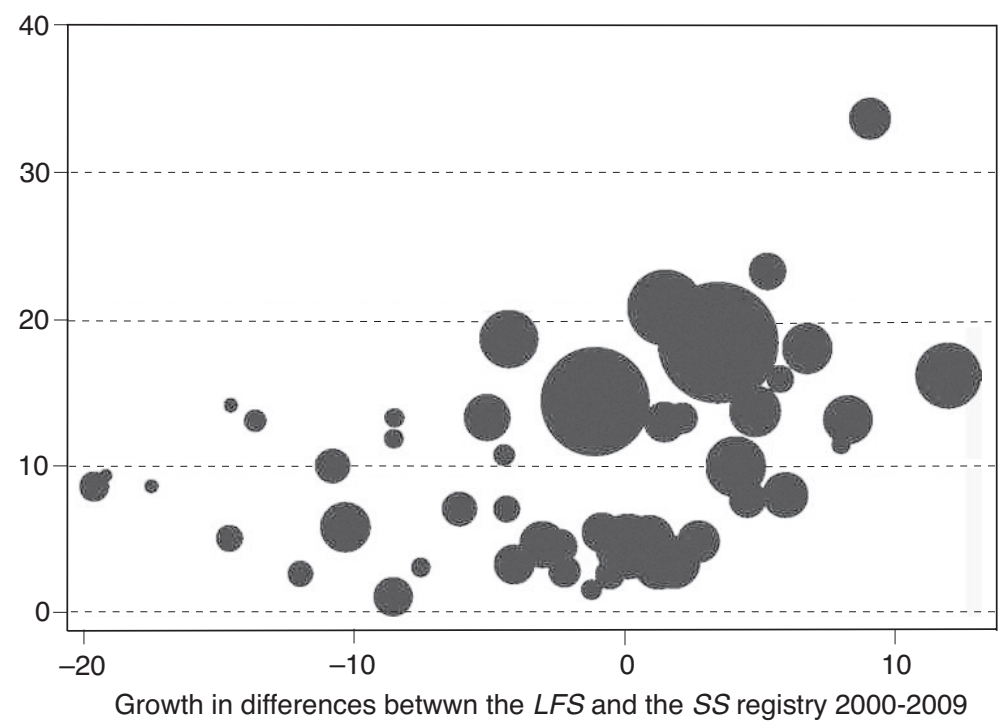

\subsection{The Empirical Model}

To investigate the effect of immigration on the discrepancies between the Labor Force Survey and the Social Security records we estimate the following empirical model:

$$
\Delta_{r t}=\alpha+\phi_{r}+\gamma_{t}+\text { Bimmigrant_share }{ }_{r t}+u_{r t}
$$

where $\Delta_{r t}$ is the difference between the number of employed individuals in the Labor Force Survey and those in the Social Security records in province $r$ and year $t$. The difference is normalized using the number of employed individuals in the Labor Force Survey in the corresponding cell $(r, t)$. Our main explanatory variable is the share of immigrants, immigrant_share ${ }_{r t}$, defined as the percentage of working age foreign born individuals over the total working age population in a given province, $r$, and year, $t$. Notice that equation [1] includes year, $\gamma_{t}$, and province, $\phi_{r}$, fixed effects, thus identification of our main coefficient of interest, $\beta$, comes from comparing changes in the differences between the LFS and the $S S$ within provinces and over time, in high versus low immigration provinces.

As argued in the previous section the difference between the LFS and the SS records do not only respond to undocumented work. However, as long as changes in this difference unrelated to irregular activities are constant over time or within provinces, or uncorrelated to the stock of immigrants (e.g. the size of the clergy, self- 
employed workers with a second contract or civil servants with private affiliation), the $\beta$ coefficient in equation [1] will identify the effect of immigration on the size of the informal labor market. We think this is a reasonable assumption, particularly when we exclude from the analysis workers in the agriculture sector.

We also investigate the effect of the 2005 amnesty on the size of the informal labor market. The aim of the regularization process was to legalize the employment of the large number of illegal aliens (see Figure 2), and thus decrease the size of the shadow economy. To assess the effectiveness of the policy we estimate the following empirical model:

$$
\Delta_{r t}=\alpha+\phi_{r}+\gamma_{t}+\text { Bimmig_share } r \text { samnesty }{ }_{0.5}+\text { Oimmig_share }_{r t} * \text { amnesty }_{0.5}+u_{r t}
$$

The amnesty $y_{0.5}$ variable is an indicator that takes value 1 from 2005 onwards and 0 for the previous years. Thus $\delta$ measures the impact of the regularization on the size of the informal economy. Finally, the coefficient on the interaction between the immigrant share and the amnesty indicator, $\theta$, is informative of any change in the relationship between immigration and informality as a result of the regularization process.

Identification of the model coefficients in equation [1] and [2] exploits the geographical differences in the concentration of immigrations across Spanish provinces. As in previous immigration studies, the spatial correlation approach adopted here may suffer from endogeneity if the flow of immigrants towards particular provinces is not exogenous to the particular economic phenom $\beta \beta$ ena we are interested in. In order to circumvent this problem we employ the classical instrumental variable approach based on ethnic networks. This approach isolates the variation in immigrant concentration across provinces that results from recent immigrants locating in provinces with large communities of previous immigrants from the same country of origin.

More formally, consider the following predictor for the size of the immigrant population in a province $r$ in a given year $t$ :

$$
Z_{r, j}=\sum_{c} Z_{c, r, t}=\sum_{c}\left(\frac{F B_{r, c, t_{0}}}{F B_{c, t_{0}}}\right) F B_{c, t}
$$

for $t_{0}<t$. The term in brackets denotes the share of the foreign-born population from country of origin $c$ living in Spain's province $r$ in some base year $t_{0}$. As discussed below the base year in this analysis is $1991 . F B_{c, t}$ is the total size of the population from country $c$ residing in Spain in year $t$. We obtain the instrument by adding up the predicted share of immigrants by country of origin in each province, $Z_{r, t}$, and normalizing it by the working age population in the cell $(r, t)$.

The instrument based on ethnic networks has been widely used in the US (Card, 2001), but less in countries with a much recent immigration history such as Spain. Intuitively, the instrument reassigns the current stock of immigrants across provinces 
according to the historical settlements of their country men. The immigration process to Spain started timidly at the beginning of the 1990s, thus we use the geographical distribution of immigrants across Spanish provinces in 1991 as a base year to construct our instrument.

The validity of the ethnic networks instrument based on the 1991 historical settlements depends on two crucial assumptions. First, the location decisions of immigrants prior to 1991 across Spanish provinces have to be uncorrelated with unexpected changes or transitory shocks to the size of the provincial shadow economies between 2000 and 2009. This assumption can not be empirically tested, however the geographic dispersion of immigrants by country of origin across Spanish provinces suggest that economic reasons cannot be the only determinant of immigrant location decisions. For example, Moroccans are overrepresented in the Mediterranean coast such as Murcia, Alicante and Girona; while South-Americans are popular in the Canary Islands and the North-Western provinces of the country. This evidence, at least for Moroccans, suggests that geographical proximity to the country of origin is an important determinant of their location decisions. The geographical choices of South- Americans may be linked to the presence of Spanish returnees from previous emigration episodes, originally from Galicia and the Canary Islands.

The second assumption that the instrument requires is that the immigrant settlements established before 1991 have to be able to predict the location decisions of new arrivals from the same country 8 to 18 years latter. This assumption can be tested in our first-stage regressions, from where we can assess the predictive power of the predicted share of immigrants in explaining the current distribution of immigrants across Spanish provinces. We present the first-stage results shortly, but first we focus on the OLS estimates of the models in equation [1] and [2].

Table 1 present the estimates of the models in equation [1] and [2] respectively. The dependent variable in both equations, the difference in employment according to the $L F S$ and the $S S$ records normalized by the level of employment in the $L F S$, is measured as an annual average for the period 2000-2009 ${ }^{10}$. We use the Population Registry to compute the annual share of foreign born population at the provincial level ${ }^{11}$. Thus our sample consists of 500 observations (10 years and 50 Spanish provinces ${ }^{12}$ ). To obtain robust estimates of the variance-covariance matrix we weight the observations using the province population at time $t$.

Column (1) and (2) in Table 1 report the OLS estimates of the model in equation [1] and [2]. The estimated coefficient on the share of immigrants indicates that a 1

\footnotetext{
${ }^{10}$ Note that the $L F S$ is a quarterly survey, while the information in the $S S$ records is released on a monthly basis.

${ }^{11}$ See FARRÉ, GONZÁLEZ and ORTEGA (2010) for a discussion on the advantages of using the Population Registry in measuring the local concentration of immigrants in Spain.

${ }^{12}$ We exclude Ceuta and Melilla from the analysis as the concentration of immigrants in that region was already very high at the beginning of the period.
} 
percentage point increase in the share of the foreign born population in a province increases the share of unregistered work by 0.3 percentage points. This relationship does not seem to change after the amnesty took place in 2005. Our estimates indicate that while the amnesty represented a significant reduction in the size of the informal sector (i.e. in the average province and for the period 2005 to 2009 the size of the informal labor market declined by about 1.5 percentage points), it did not managed to significantly change the relationship between immigration and informality. Thus the coefficient on the interaction between the immigrant provincial concentration and the amnesty indicator is not statistically significant.

Columns (3) and (4) in the same table report the IV estimates of the model when using the ethnic networks instrument. If we first examine the first-stage results associated to these regressions and reported in Table 2, we can conclude that our instrument, the predicted share of immigrants, is a strong predictor of the current provincial distribution of immigrants. A coefficient of 0.289 , with a t-statistic of 11.13 and an associated F-test of 108.04 clearly rejects the hypothesis of weak instruments. The 4 estimates in columns (3) and (4) in Table 1 are larger than the OLS results, but the coefficients are somehow estimated with less precisions. However, they still support the main conclusion in the OLS estimation. That is, immigration has a positive impact on the size of the informal labor market and though the 2005 amnesty decreased the size of the informal economy it does not affected the relationship between immigration and underground economy at the provincial level.

In interpreting the effects of the 2005 amnesty one should bear in mind that the regularization occurred during the largest economic expansion of the Spanish economy in decades. While the amnesty managed to legalize many immigrants (about 600,000) and thus reduced the size of the black economy, illegal aliens continued to enter the country attracted by the many job opportunities available. Our estimates indicate that the amnesty was indeed unsuccessful in affecting the relationship between immigration and the size of the informal labor market.

\subsection{Robustness checks}

In Table 3 we conduct a series of checks to assess the robustness of our results. First, since the agricultural sector may be responsible for part of the inconsistencies between the LFS and the Social Security records, we estimate the same regressions as in Table 1 but using data only from the manufacturing and the service sector. The results reported in column (1) and (2) of Table 3 indicate that the relationship between immigration and the informal sector are reinforced when the agricultural sector is excluded from the sample.

Columns (3) and (4) show the unweighted regressions. The results are qualitatively the same as in Table 1 but quantitatively stronger indicating that the relationship between immigration and the informal sector is stronger in provinces with less population. Columns (5) and (6) try to control for any labor market characteristics 
that can spuriously generate the observed relationship between immigration and the size of the shadow economy. In particular, one could suspect that provinces with particular labor market characteristics or industry structure are more prone to both receive more immigrants and have more unregistered work. Using data from the $L F S$ in 2000 we calculate the participation rate, unemployment rate, share of occupied population in the industry, service and construction sectors. We allow for different provinces to have different trends of unregistered employment along those dimensions. We do not find any significant differences with previous results.

To close our analysis Table 4 investigates the implications of the economic recession inaugurated in the mid-2007. As discussed, one the most dramatic consequence of the economic downturn has been the increase in the unemployment rate (from $8.53 \%$ in 2006 to $24.63 \%$ in 2012). Several studies investigate the relationship between the economic cycle and the size of informal labor market. There seems to be the consensus that the share of informal employment is countercyclical in most developed countries (Loayza and Rigolini, 2007, and Boeri and Gribaldi, 2006), however episodes of procyclical behavior have also been identified in some middle income countries such as Brazil, Colombia and Mexico (Fiess et al., 2008).

To start the analysis we first replicate the estimations in Table 1 with additional data for the period 2010-2012. The first column in Table 4 presents the IV estimates of the model in equation [1] and the second those of equation [2]. The estimated coefficients indicate a stronger relationship between immigration and the share of the informal economy than when the sample is restricted to the period 20002009. In particular, a 1 percentage point increase in the share of the foreign born population in a province increases the share of unregistered work in that province by approximately 1 percentage point.

To investigate the implications of the economic recession the model in equation [1] is extended by including an indicator variable that takes value 1 if the observation corresponds to the period 2008-2012 and 0 otherwise (i.e.crisis indicator). The model also includes an interaction between this indicator and the share of immigrants in the province (i.e. crisis $\times$ share of immigrants). The IV estimates reported in column 3 indicate that the relationship between the presence of immigrants and the size of the informal economy is slightly higher during the recessionary period. That is, for the period 2008-2012 a 1 percentage point increase in the share of the foreign born population in a province increases the share of unregistered work by 0.9 percentage points, while this increase is only of 0.7 percentage points before the economic collapse. Interestingly, the results also indicate that the share of unregistered work decreased during the economic downturn. This may result from the large concentration of informal workers in the construction sector, who were unable to find jobs in alternative sectors after the burst of the real-state bubble. Finally the last column in Table 4 includes the crisis and the amnesty indicators as well as their interaction with the share of immigrants. Since there is a substantial overlap between the periods identified by those indicators, its effects cannot be separately identified. 
TABLE 1

RELATIONSHIP BETWEEN SHARE OF IMMIGRANTS AND INFORMAL ECONOMY

\begin{tabular}{|l|c|c|c|c|}
\hline & OLS & OLS & IV & IV \\
\hline Share of Immigrants & $\begin{array}{c}0,304 * * \\
(0,124)\end{array}$ & $\begin{array}{c}0,343^{* * *} \\
(0,119)\end{array}$ & $\begin{array}{c}0,781^{* * *} \\
(0,218)\end{array}$ & $\begin{array}{c}0,792^{* * *} \\
(0,293)\end{array}$ \\
\hline Amnesty & & $\begin{array}{c}-1,522 \\
(1.776)\end{array}$ & & $\begin{array}{c}-7,078 * * * \\
(2.697)\end{array}$ \\
\hline Amnesty X Share & & $\begin{array}{c}-0,0291 \\
(0.0654)\end{array}$ & & $\begin{array}{c}0.00378 \\
(0.116)\end{array}$ \\
\hline Observations & & 500 & 500 & 500 \\
\hline $\mathrm{R}^{2}$ & 500 & 0.834 & 0.814 & 0.814 \\
\hline
\end{tabular}

TABLE 2

FIRST-STAGE RESULTS

\begin{tabular}{|l|c|c|}
\hline & OLS & OLS \\
\hline Instrument & $\begin{array}{c}0.289 * * * \\
(0.026)\end{array}$ & $\begin{array}{c}0.348 * * * \\
(0.052)\end{array}$ \\
\hline Amnesty X Instrument & & $\begin{array}{c}-0.041 \\
(0.453)\end{array}$ \\
\hline Observations & 500 & 500 \\
\hline $\mathrm{R}^{2}$ & 0.927 & 0.930 \\
\hline F-test & 108.04 & 111.27 \\
\hline
\end{tabular}

NOTE: The dependent variable in the regressions is the share of immigrants. 
TABLE 3

ROBUSTNESS CHECKS

\begin{tabular}{|c|c|c|c|c|c|c|}
\hline \multirow{2}{*}{} & \multicolumn{2}{|c|}{ No Agriculture } & \multicolumn{2}{c|}{ Unweighted } & \multicolumn{2}{c|}{ Province Trends } \\
\cline { 2 - 7 } & IV & IV & IV & IV & IV & IV \\
\hline Share of Immigrants & $0.930^{* * *}$ & $\begin{array}{c}0.865^{* * *} \\
(0.207)\end{array}$ & $\begin{array}{c}1.361 * * * \\
(0.300)\end{array}$ & $\begin{array}{c}1.268 * * * \\
(0.540)\end{array}$ & $\begin{array}{c}1.051^{* * *} \\
(0.507)\end{array}$ & $\begin{array}{c}1.020 * * * \\
(0.391)\end{array}$ \\
\hline Amnesty & & $\begin{array}{c}-8.673 * * * \\
(2.529)\end{array}$ & & $\begin{array}{c}-12,91 * * * \\
(4.306)\end{array}$ & & $\begin{array}{c}4.384 \\
(15.10)\end{array}$ \\
\hline Amnesy X Share & & 0.0383 & & 0.0388 & & 0.0373 \\
& & $(0.118)$ & & $(0.162)$ & & $(0.117)$ \\
\hline & 500 & 500 & 500 & 500 & 500 & 500 \\
\cline { 2 - 7 } & 0.827 & 0.829 & 0.693 & 0.700 & 0.796 & 0.795 \\
\hline
\end{tabular}

TABLE 4

ROBUSTNESS CHECKS (TIME PERIOD 2000-2012)

\begin{tabular}{|c|c|c|c|c|}
\hline & IV & IV & IV & IV \\
\hline Share of Immigrants & $\begin{array}{c}1.083 * * * \\
(0.178)\end{array}$ & $\begin{array}{c}1.071 * * * \\
(0.298)\end{array}$ & $\begin{array}{c}0.698 * * * \\
(0.196)\end{array}$ & $\begin{array}{c}1.268 * * \\
(0.507)\end{array}$ \\
\hline Amnesy & & $\begin{array}{c}-10.91 * * * \\
(1.312)\end{array}$ & & $\begin{array}{l}-1.297 \\
(1.218)\end{array}$ \\
\hline Amnesty X Share & & $\begin{array}{l}0.0133 \\
(0.120)\end{array}$ & & $\begin{array}{l}-0.077 \\
(0.122)\end{array}$ \\
\hline Crisis & & & $\begin{array}{c}-8.790 * * * \\
(1.197)\end{array}$ & $\begin{array}{c}-8.067 * * * \\
(1.375)\end{array}$ \\
\hline \multirow[t]{3}{*}{ Crisis X Share } & & & $\begin{array}{c}0.185 * * * \\
(0.0900)\end{array}$ & $\begin{array}{l}0.173 * \\
(0.097)\end{array}$ \\
\hline & 650 & 650 & 650 & 650 \\
\hline & 0.785 & 0.787 & 0.786 & 0.783 \\
\hline
\end{tabular}




\section{Conclusions}

The economic expansion in developed countries during the last decade has led to an extraordinary large inflow of immigrants from less developed economies. Attracted by the job magnet and discouraged by the scarcity of legal entry channels, many of them have surreptitiously crossed the borders. This large supply of irregular workers have boosted the underground economy, particularly in countries where irregular economic activities are not unpopular such in Southern European countries.

This paper investigates the relationship between immigration and the size of the informal labor market in Spain. Our estimates suggests that the 12 percentage points increase in the foreign born population between 2000 and 2009 accounted for at least a $70 \%$ of the overall increase in unreported employment. In an attempt to remove illegal aliens from the Spanish labor market, the government granted amnesty to about 700,000 workers in 2005 . Through this regularization process an important fraction of the illegally resident population was legalized and thus the share of undocumented employment decreased by at least 2 percentage points. However, illegal immigrants continued to arrive attracted by the prosperity of the economy, the weak border enforcement and the minimal employer sanctions. Hence, the relationship between immigration and the size of the shadow economy remained unaffected after the amnesty.

With this paper we uncover an important positive relationship between immigration and the size of the informal labor market. We also show that amnesties are not effective in affecting this relationship, at least if they are implemented during periods of high economic growth. Accordingly, guest-worker programs and a stronger enforcement of the immigration laws, both at the borders and the work place, seem a more effective way to fight illegal alien employment.

Finally we also show that the relationship between immigration and the size of the informal economy is slightly modify during recessionary periods.

\section{References}

[1]BOERI, T. and GARIBALDI, P. (2006): «Shadow Activity and Unemployment in a Depressed Labor Market», IGIER Working paper No. 77, Bocconi University, IGIER, Milano, Italy.

[2] CARD, D. (2001): «Immigrant Inflows Native Outflows, and the Local Labor Market Impacts of Higher Immigration», Journal of Labor Economics 19: January, pp. 22-64.

[3] CARRASCO, R.; JIMENO, J. F and CAROLINA ORTEGA, A. (2008): «The Effects of Immigration on the Labor Market Performance of Native-Born Workers: Some Evidence for Spain», Journal of Population Economics, 21(3), 627-648.

[4] CHISWICK, B. (1998): «Illegal Immigration and Immigration Control», Journal of Economic Prespectives, 2(3): 101-115.

[5] EC (1998): «Communication of the Commission on Undeclared Work", COM (1998) 219 (http://europa.eu.int/comm/employment_social/empl_esf/docs/com98-219_en.pdf) 
[6] FARRÉ L.; GONZÁLEZ, L. and ORTEGA, F. (2010): «Immigration, Family Responsibilities and the Labor Supply of Skilled Native Women», INSIDE Working Paper.

[7] FIESS, N.; FUGAZZA, M. and MALONEY, W. (2008): «Informal Labor Markets and Macro Economic Fluctuations», IZA Working Paper 3519.

[8] GONZÁLEZ, L. and ORTEGA, F. (2010): «How do very open economies adjust to large immigration flows? Recent evidence from Spanish regions», Forthcoming Labor Economics.

[9] LOAYZA, N. and RIGOLINI, J. (2006): «Informality Trends and Cycles», World Bank Policy Research Working Paper 4078, Washington DC

[10] MINISTRY OF LABOR AND FOREIGN AFFAIRS. Several years. http://extranjeros. mtas.es.

[11] OECD (1986): «Concealed Employment», Chapter 3, Employment Outlook, Paris.

[12] OECD (2009): «International Immigration Outlook».

[13] SCHNEIDER, F. and ENSTE, D. (2000): «Shadow Economies: Size, Causes and Consequences», Journal of Economic Literature, 38: 77-114.

[14] SCHNEIDER, F. and ENSTE, D. (2002): «Hiding in the Shadows. The Growth of the Underground Economy», Economic Issue, n 30 , IMF.

[15] SPANISH ECONOMIC AND SOCIAL COUNCIL (2004): «La inmigración y el mercado de trabajo en España» 